\title{
Keragaman Agama, Etnis, Bahasa, dan Pembangunan Desa
}

\author{
Diversity of Religions, Ethnicities, Languages, and Village Development
}

\author{
Loria Sara Paais $^{1 *}$
}

\begin{abstract}
${ }^{1}$ Program Studi Magister Ekonomi Kependudukan dan Ketenagakerjaan, Fakultas Ekonomi dan Bisnis, Universitas Indonesia, Gedung Nathanael Iskandar Lantai 3, Kampus UI Depok 16424, Indonesia;

*Penulis korespondensi. e-mail: 1sarap89@gmail.com

(Diterima: 22 Februari 2021; Disetujui: 01 Mei 2021)
\end{abstract}

\begin{abstract}
The diversity of religions, ethnicities and languages that exist in Indonesia could either be a barrier or a driver for rural development and has been receiving more attention in recent years. The purpose of this study is to analyze the long-term influence of the existence of residents with different religions, ethnicities, and daily languages in a village-on-village development. This research uses descriptive analysis and inferencing with multiple linear regression. Results of the multiple linear regression analysis show that the existence of residents of different religions and ethnicities has a positive impact on village development, but the various languages used daily have the opposite effect. In addition, the existence of credit facilities received by residents, the presence of health workers in the village, and the village topography have high enough influence on village development.
\end{abstract}

Keywords: diversity of religion, ethnicity, language, village development

\begin{abstract}
ABSTRAK
Keragaman agama, etnis, dan bahasa yang ada di Indonesia dapat menjadi penghalang atau pendorong pembangunan desa dan telah mendapat perhatian lebih beberapa tahun terakhir. Tujuan dari penelitian ini adalah menganalisis pengaruh jangka panjang keberadaan warga dengan agama, etnis, dan bahasa sehari-harinya yang berbeda di suatu desa terhadap pembangunan desa. Penelitian ini menggunakan analisis deskriptif dan inferensial dengan regresi linier berganda. Hasil analisis regresi linier berganda menunjukkan bahwa keberadaan warga dari agama dan etnis yang berbeda memberikan dampak positif terhadap pembangunan desa, akan tetapi bahasa beragam yang dipakai sehari-hari memberikan dampak sebaliknya. Selain itu, keberadaan fasilitas kredit yang diterima warga, keberadaan tenaga kesehatan di desa, dan topografi desa memiliki pengaruh cukup tinggi terhadap pembangunan desa.
\end{abstract}

Kata kunci: bahasa, etnis, keragaman agama, pembangunan desa

\section{PENDAHULUAN}

Dalam beberapa tahun terakhir, fokus pembangunan yang baru di Indonesia telah bergeser dari kota ke desa, salah satunya melalui peningkatan pembangunan infrastruktur di desa. Selain itu, pemberdayaan ekonomi komunitas desa dan pembangunan sumber daya manusia di desa juga menjadi salah satu karakteristik dari pembangunan yang baru di Indonesia (Nurlinah et al., 2020).

Lima belas tahun setelah kebijakan desentralisasi, pemerintah pusat menetapkan Undang-Undang No. 6 Tahun 2014 tentang 
Desa yang memberikan kewenangan tertentu sampai ke tingkat desa. Otoritas yang diberikan sampai pada tingkat desa diharapkan dapat lebih memberdayakan komunitas lokal dalam menentukan pembangunan yang dibutuhkan dan dapat menyelesaikan masalah di desa tersebut secara langsung (Faoziyah \& Salim, 2020).

Menurut data Badan Pusat Statistik (BPS) jumlah desa menurut klasifikasi pemerintah terus meningkat. Pada tahun 2011, jumlah desa menurut klasifikasi pemerintah sebanyak 70,390 desa. Tahun 2014 dan 2018, jumlah desa bertambah menjadi masing-masing sebanyak 73,707 dan 75,436 desa (BPS, 2011b; 2014; 2018c). BPS memproyeksikan pada tahun 2040 jumlah penduduk di perdesaan sebanyak 93.06 juta penduduk (BPS, 2018b). Hal tersebut menunjukkan bahwa pembangunan desa masih mempengaruhi banyak penduduk bahkan sampai 20 tahun mendatang.

Pembangunan desa sejalan dengan salah satu Tujuan Pembangunan Berkelanjutan (TPB), yaitu mengurangi kesenjangan intranegara dimana jumlah desa tertinggal dan jumlah desa mandiri menjadi indikator nasional sebagai proksi global dari tujuan tersebut (Bappenas, 2017). Selama ini, pembangunan cenderung bias perkotaan, sehingga pembangunan desa dapat dilakukan untuk mengurangi kesenjangan pembangunan perkotaan dan perdesaan (BPS, 2018a).

Desa yang tertinggal dianggap sebagai salah satu faktor yang signifikan berkontribusi terhadap kesenjangan, dimana tingkat kemiskinan di perdesaan lebih tinggi bila dibandingkan di perkotaan (Salim et al., 2017). Berdasarkan data BPS, dari tahun 2005 sampai 2019, persentase penduduk miskin di perdesaan selalu lebih tinggi dibandingkan di perkotaan. Tahun 2019, persentase penduduk miskin di perdesaan sebesar 12.85 persen sedangkan di perkotaan sebesar 6.69 persen. Rata-rata lama sekolah di perdesaan juga lebih rendah dibandingkan di perkotaan, dimana pada tahun 2019 rata-rata lama sekolah di perkotaan sebesar 9.73 tahun sedangkan di perdesaan sebesar 7.48 tahun yang mana belum memenuhi program wajib belajar sembilan tahun. Pelayanan kesehatan di perdesaan juga masih lebih rendah dibandingkan di perkotaan. Tahun 2019, unmeet need pelayanan kesehatan di perdesaan sebesar 6.15 persen, lebih tinggi bila dibandingkan di perkotaan yang sebesar 4.41 persen.

Tahun 2018, berdasarkan data BPS terdapat 5,559 desa mandiri, 54,879 desa berkembang, dan 13,232 desa tertinggal. Jumlah desa tertinggal masih dua kali lipat dibandingkan jumlah desa mandiri atau 17.96 persen dari seluruh desa di Indonesia. Pada tahun 2018, di Indonesia, masih terdapat 72,863 desa tanpa bank, 27,435 desa yang tidak dilewati angkutan umum, 29,650 desa yang memiliki paling sedikit satu keluarga tanpa akses listrik, 58,277 desa tanpa kelompok pertokoan dan pasar, 27,710 desa dimana sebagian besar keluarga yang tinggal di desa tersebut menggunakan kayu bakar sebagai bahan bakar utama untuk memasak, serta 6,759 desa yang tidak terdapat sinyal telepon selular (BPS, 2018c).

Progres pembangunan di daerah perdesaan masih rendah di beberapa negara berkembang (Barrios, 2008). Beberapa masalah yang dihadapi daerah perdesaan di antaranya sulit mengadopsi teknologi, sulit berpartisipasi dalam kegiatan sosial ekonomi karena konektivitas yang buruk serta sulit dan mahal untuk menyediakan layanan publik (Cowie et al., 2020).

Marsden (2010) menyatakan bahwa terdapat enam kunci pembangunan desa, yaitu faktor endogen, pembaruan, modal sosial, tata kelola pasar, institusi baru, dan keberlanjutan. Faktor endogen merupakan faktor yang berasal dari dalam desa, diantaranya sumber daya lokal, kombinasi sumber daya lokal serta distribusi dan investasi dari kekayaan yang dihasilkan dari sumber daya lokal. Pembaruan merupakan wawasan baru, praktek baru, kombinasi dari sumber daya, teknologi, pengetahuan yang baru yang dapat memberikan fungsi yang lebih baik. Modal sosial menggambarkan kemampuan individu, grup, organisasi atau institusi, untuk terlibat dalam tujuan dan keuntungan yang sama. Pembangunan desa juga memerlukan tata kelola pasar untuk mengendalikan pasar atau 
membangun pasar baru, institusi baru yang dapat berfungsi untuk mengkoordinasi masalah dan memberikan dukungan untuk tokoh desa, serta pembangunan ekonomi dan budaya desa yang berkelanjutan (Marsden, 2010).

Indonesia memiliki 6 agama yang diakui, sekitar 1,340 suku bangsa, dan sekitar 2,500 bahasa daerah (BPS, 2011a). Hal tersebut dapat menjadi potensi atau penghalang bagi pembangunan. Mengingat Indonesia memiliki tingkat keragaman yang tinggi, keragaman etnis dapat memiliki peran dalam terciptanya konflik (Anggriyani \& Dartanto, 2019). Hal tersebut dapat menjadi penghalang pembangunan.

Keragaman budaya dan bahasa dalam suatu wilayah dapat menjadi jembatan dalam melakukan perdagangan dengan wilayah lain yang dapat menopang pembangunan ekonomi (Ahmad \& Amin, 2020). Keragaman etnis juga dapat meningkatkan pembangunan melalui budaya (yang berpengaruh terhadap sumber daya manusia) dan modal sosial yang dapat meningkatkan tingkat kepercayaan dan tingkat partisipasi dalam pembangunan (Churchill et al., 2020). Keragaman agama dapat meningkatkan produktivitas, dimana individu yang beragam juga memiliki keahlian yang beragam, sehingga dapat meningkatkan pembangunan (Ying et al., 2017).

Akan tetapi, Churchill \& Smyth (2017) menemukan bahwa negara yang memiliki etnis lebih beragam lebih cenderung miskin dibandingkan negara yang memiliki etnis yang lebih homogen. Keragaman etnis dapat menimbulkan perbedaan pandangan terhadap berbagai hal yang dapat menimbulkan konflik yang dapat menghambat pembangunan (Churchill \& Smyth, 2017; Huntington, 1993).

Menurut Grabowski \& Laidler (2018) kualitas layanan pendidikan merupakan determinan dari negara yang tertinggal, dimana masyarakat yang tidak berpendidikan dapat menjadi penghalang pembangunan ekonomi suatu wilayah. Selain itu, topografi, lapangan usaha warga desa, tenaga kesehatan, irigasi, dan akses kredit, juga dapat mempengaruhi pembangunan desa (Barrios, 2008; Qin et al.,
2020; Rennie, 2003; Xiaojian \& Xinsheng, 2010).

Fokus pembangunan yang lebih mengarah ke desa memerlukan berbagai pertimbangan. Belum banyak penelitian di Indonesia mengenai pengaruh keragaman etnis, agama atau bahasa terhadap pembangunan desa, sementara Indonesia adalah negara dengan keragaman yang tinggi. Oleh karena itu, penelitian mengenai pengaruh keragaman etnis, agama, dan bahasa terhadap pembangunan desa diperlukan. Tujuan dari penelitian ini adalah mempelajari pengaruh jangka panjang dari keragaman etnis, agama, dan bahasa serta faktor-faktor lain terhadap pembangunan desa.

\section{METODOLOGI}

\section{Sumber Data}

Data yang digunakan pada penelitian ini bersumber dari Pendataan Potensi Desa 2014 (PODES2014) dan Indeks Pembangunan Desa 2018 (IPD2018). Pendataan PODES merupakan pendataan yang dilakukan BPS secara sensus terhadap seluruh kabupaten/kota, kecamatan, dan wilayah administrasi pemerintahan terendah setingkat desa, yaitu desa, kelurahan, nagari, Unit Permukiman Transmigrasi (UPT), dan Satuan Permukiman Transmigrasi (SPT). Pendataan PODES dilakukan tiga kali setiap 10 tahun dan dilakukan sebelum Sensus Pertanian, Sensus Ekonomi, dan Sensus Penduduk. Pengumpulan data PODES 2014 dilakukan dengan wawancara kepala desa, sekretaris desa, kaur/kasi desa, dan pada instansi terkait seperti PLN, Puskesmas, atau Telkom (BPS, 2014).

IPD merupakan indeks yang mengukur tingkat kemajuan desa yang dihasilkan oleh BPS dengan menggunakan sumber data PODES. Penghitungan IPD2018 hanya dilakukan untuk seluruh wilayah administrasi desa di seluruh Indonesia. Desa dalam penghitungan IPD merupakan desa berdasarkan Undang-Undang No. 6 Tahun 2014 tentang Desa. Pembangunan desa merupakan konsep yang multidimensi sehingga IPD dibangun berdasarkan 5 dimensi yaitu pelayanan dasar, kondisi infrastruktur, aksesibilitas/transportasi, pelayanan umum, dan 
penyelenggaraan pemerintahan. Kelima dimensi tersebut dihitung menggunakan Principal Component Analysis dari 42 indikator yang terdapat dalam data PODES. Nilai IPD setiap desa bernilai dari 0 sampai 100. Semakin tinggi nilai IPD menunjukkan desa yang semakin maju. Dalam pengkategorian, desa dengan nilai IPD lebih dari 75 dikategorikan sebagai desa mandiri, IPD lebih dari 50 sampai kurang dari atau sama dengan 75 dikategorikan sebagai desa berkembang, dan IPD bernilai kurang dari atau sama dengan 50 dikategorikan sebagai desa tertinggal (BPS, 2018a). Dimensi dan indikator yang digunakan dalam IPD ditunjukkan pada Tabel 1.

Tabel 1. Dimensi dan indikator IPD

\section{Indikator}

\section{Dimensi Pelayanan Dasar}

Ketersediaan dan akses ke TK/RA/BA

Ketersediaan dan akses ke SD Sederajat

Ketersediaan dan akses ke SMP Sederajat

Ketersediaan dan akses ke SMA Sederajat

Ketersediaan dan kemudahan akses ke rumah sakit

Ketersediaan dan kemudahan akses ke RS Bersalin

Ketersediaan dan kemudahan akses ke Puskesmas

Ketersediaan dan kemudahan akses ke

Poliklinik/Balai Pengobatan

Ketersediaan dan kemudahan akses ke tempat praktek dokter

Ketersediaan dan kemudahan akses ke tempat praktek bidan

Ketersediaan dan kemudahan akses ke Poskesdes atau Polindes

Ketersediaan dan kemudahan akses ke apotek

\section{Dimensi Kondisi Infrastruktur}

Ketersediaan pertokoan, minimarket atau toko/warung kelontong

\section{Indikator}

Ketersediaan pasar

Ketersediaan restoran, rumah makan atau warung/kedai makanan minuman

Ketersediaan akomodasi hotel atau penginapan

Ketersediaan bank

Elektrifikasi

Kondisi penerangan di jalan utama desa

Bahan bakar untuk memasak

Sumber air untuk minum

Sumber air untuk mandi/cuci

Fasilitas buang air besar

Ketersediaan dan kualitas komunikasi seluler

Ketersediaan fasilitas internet dan pengiriman pos atau barang

\section{Dimensi Akuntabilitas Transportasi}

Lalu lintas dan kualitas jalan

Aksesibilitas jalan

Ketersediaan angkutan umum

Operasional angkutan umum

Waktu tempuh per kilometer transportasi ke kantor camat

Biaya per kilometer transportasi ke kantor camat

Waktu tempuh per kilometer transportasi ke kantor Bupati/Walikota

Biaya per kilometer transportasi ke kantor Bupati/Walikota

\section{Dimensi Pelayanan Umum}

Penanganan kejadian luar biasa

Penanganan gizi buruk

Ketersediaan fasilitas olahraga

Keberadaan kelompok kegiatan olahraga

\section{Dimensi Penyelenggaraan Pemerintah}

Kelengkapan pemerintahan desa 


\begin{tabular}{l}
\hline \multicolumn{1}{c}{ Indikator } \\
\hline Otonomi desa \\
\hline Aset/Kekayaan Desa \\
\hline Kualitas SDM Kepala Desa \\
\hline Kualitas SDM Sekretaris Desa \\
\hline Sumber : BPS (2018a)
\end{tabular}

\section{Unit Analisis}

Unit analisis yang digunakan dalam penelitian ini adalah desa berdasarkan konsep desa pada Undang-Undang No. 6 Tahun 2014 tentang Desa. Desa adalah kesatuan masyarakat hukum yang memiliki batas wilayah yang berwenang untuk mengatur dan mengurus urusan pemerintahan, kepentingan masyarakat setempat berdasarkan prakarsa masyarakat, hak asal usul, dan/atau hak tradisional yang diakui dan dihormati dalam sistem pemerintahan Negara Kesatuan Republik Indonesia (BPS, 2018a).

Berdasarkan data PODES jumlah desa di seluruh Indonesia tahun 2014 sebanyak 73,707 desa, sedangkan tahun 2018 sebanyak 75,436 desa. Data IPD2018 yang dihasilkan oleh BPS mencakup 75,436 desa tahun 2018.

Dikarenakan variabel bebas pada penelitian ini bersumber dari data PODES2014 dan variabel terikat bersumber dari IPD2018 maka unit analisis pada penelitian ini merupakan desa-desa di tahun 2014 yang dihitung IPD-nya pada tahun 2018. Mengingat dari tahun 2014 sampai tahun 2018 perubahan administratif suatu desa dapat terjadi seperti penggabungan beberapa desa atau perubahan status dari desa menjadi kelurahan dan data cleaning, setelah melakukan penggabungan data PODES2014 dan IPD2018 maka jumlah desa yang dianalisis pada penelitian ini adalah sebesar 72,121 desa.

\section{Variabel}

Variabel yang diteliti pada penelitian ini terbagi menjadi variabel terikat, variabel bebas utama, dan variabel bebas kontrol. Variabel terikat yaitu pembangunan desa pada penelitian ini menggunakan nilai IPD2018. Variabel bebas utama dan variabel bebas kontrol bersumber dari PODES2014. Variabel bebas utama adalah variabel bebas yang merupakan fokus dari penelitian ini, yaitu keragaman agama, keragaman etnis, dan keragaman bahasa. Keragaman agama dalam penelitian ini dikategorikan berdasarkan keberadaan warga yang berbeda agama dalam satu desa atau terdapat lebih dari satu agama yang dianut oleh masyarakat di desa tersebut. Desa dengan warga yang menganut lebih dari satu agama dikategorikan sebagai multi agama. Keragaman etnis dilihat dari jumlah etnis dari warga desa tersebut. Jika warga berasal dari satu etnis maka tidak dikategorikan sebagai multi etnis dan sebaliknya. Variabel multibahasa merupakan bahasa yang digunakan oleh warga desa seharihari. Bahasa dalam penelitian ini dapat merupakan Bahasa Indonesia, bahasa asing, atau bahasa daerah. Bila warga menggunakan lebih dari satu bahasa sehari-hari maka desa tersebut dikategorikan sebagai multibahasa.

Dikarenakan kebanyakan variabel terikat tidak hanya dipengaruhi oleh satu variabel bebas (selain variabel bebas utama), maka variabel bebas kontrol, yaitu variabel lain yang mungkin memengaruhi variabel terikat, digunakan untuk mengontrol pengaruh variabel bebas utama terhadap variabel terikat (Harsono, 2002). Variabel bebas kontrol yang digunakan pada penelitian ini berdasarkan penelitian-penelitian sebelumnya yang telah dijelaskan pada bagian pendahuluan. Variabel terikat dan variabel bebas yang digunakan dalam analisis ini dijelaskan pada Tabel 2.

Tabel 2. Definisi operasional variabel

\begin{tabular}{llll}
\hline Variabel & $\begin{array}{c}\text { Nama } \\
\text { Variabel }\end{array}$ & Definisi & Skala \\
\hline Variabel Terikat & & \\
\hline IPD & ipd & $\begin{array}{l}\text { Indeks } \\
\text { Pembangun } \\
\text { an Desa }\end{array}$ & Kontinu \\
& & \\
\hline
\end{tabular}

Variabel Bebas Utama 


\begin{tabular}{|c|c|c|c|}
\hline Variabel & $\begin{array}{c}\text { Nama } \\
\text { Variabel }\end{array}$ & Definisi & Skala \\
\hline Multi agama & agama & $\begin{array}{l}\text { Keberadaan } \\
\text { lebih dari } \\
\text { satu agama } \\
\text { yang dianut } \\
\text { warga di } \\
\text { desa }\end{array}$ & $\begin{array}{l}0=\text { Tidak } \\
1=\mathrm{Ya}\end{array}$ \\
\hline Multi etnis & etnis & $\begin{array}{l}\text { Keberadaan } \\
\text { lebih dari } \\
\text { satu etnis } \\
\text { warga di } \\
\text { desa }\end{array}$ & $\begin{array}{l}0=\text { Tidak } \\
1=\mathrm{Ya}\end{array}$ \\
\hline $\begin{array}{l}\text { Multi } \\
\text { bahasa }\end{array}$ & bahasa & $\begin{array}{l}\text { Keberadaan } \\
\text { lebih dari } \\
\text { satu bahasa } \\
\text { sehari-hari } \\
\text { yang } \\
\text { digunakan } \\
\text { warga di } \\
\text { desa }\end{array}$ & $\begin{array}{l}0=\text { Tidak } \\
1=\mathrm{Ya}\end{array}$ \\
\hline \multicolumn{4}{|c|}{ Variabel Bebas Kontrol } \\
\hline Topografi & tpgf & $\begin{array}{l}\text { Letak } \\
\text { sebagian } \\
\text { besar } \\
\text { wilayah } \\
\text { desa }\end{array}$ & $\begin{array}{l}0= \\
\text { Bukan } \\
\text { dataran } \\
\text { (Lereng } \\
\text { atau } \\
\text { gunung } \\
\text { atau } \\
\text { lembah) } \\
1= \\
\text { Dataran }\end{array}$ \\
\hline $\begin{array}{l}\text { Lapangan } \\
\text { usaha }\end{array}$ & lapus & $\begin{array}{l}\text { Sektor } \\
\text { lapangan } \\
\text { usaha } \\
\text { sebagian } \\
\text { besar } \\
\text { penduduk } \\
\text { desa }\end{array}$ & $\begin{array}{l}0= \\
\text { Pertanian } \\
1=\text { Non } \\
\text { pertanian }\end{array}$ \\
\hline $\begin{array}{l}\text { Perguruan } \\
\text { Tinggi }\end{array}$ & $p t$ & $\begin{array}{l}\text { Jumlah } \\
\text { Perguruan } \\
\text { Tinggi di } \\
\text { desa }\end{array}$ & Kontinu \\
\hline $\begin{array}{l}\text { Lembaga } \\
\text { keterampila } \\
n\end{array}$ & terampil & $\begin{array}{l}\text { Jumlah } \\
\text { lembaga } \\
\text { keterampila } \\
\text { n di desa, } \\
\text { seperti } \\
\text { bahasa } \\
\text { asing, } \\
\text { komputer, } \\
\text { dll }\end{array}$ & Kontinu \\
\hline
\end{tabular}

\begin{tabular}{lcll}
\hline Variabel & $\begin{array}{c}\text { Nama } \\
\text { Variabel }\end{array}$ & Definisi & Skala \\
\hline $\begin{array}{l}\text { Tenaga } \\
\text { kesehatan }\end{array}$ & nakes & $\begin{array}{l}\text { Jumlah } \\
\text { tenaga } \\
\text { kesehatan } \\
\text { yang tinggal } \\
\text { di desa }\end{array}$ & Kontinu \\
& & \\
\hline Irigasi & irigasi & $\begin{array}{l}\text { Keberadaan } \\
\text { saluran }\end{array}$ & $0=$ Tidak \\
& & $\begin{array}{l}\text { ada } \\
\text { irigasi di } \\
\text { desa }\end{array}$ & $1=$ Ada \\
& & $\begin{array}{l}\text { Keberadaan } \\
\text { fasilitas } \\
\text { kredit yang } \\
\text { diterima } \\
\text { Kredit }\end{array}$ & $0=$ Tidak \\
& kredita \\
& & \\
& & setahun \\
terakhir & \\
& &
\end{tabular}

Variabel bebas yang digunakan dalam penelitian ini bukan merupakan variabel pembentuk IPD. Pada IPD terdapat indikator jumlah dan kemudahan akses ke tempat fasilitas kesehatan seperti rumah sakit, tempat praktek dokter atau tempat praktek bidan yang menghitung tempat fasilitas kesehatan yang berada di desa, serta kemudahan akses ke fasilitas kesehatan tersebut (terdekat) jika fasilitas kesehatan tersebut tidak ada di desa. Pada variabel bebas terdapat jumlah tenaga kesehatan yang merupakan jumlah seluruh dokter umum/spesialis, dokter gigi, bidan, apoteker/asisten apoteker, tenaga kesehatan masyarakat, tenaga gizi, perawat, dan tenaga kesehatan lainnya yang tinggal/menetap di desa.

\section{Metode Analisis}

Metode analisis yang digunakan dalam penelitian ini adalah analisis deskriptif dan analisis inferensial. Analisis deskriptif digunakan untuk peringkasan data (seperti proporsi) menggunakan tabel untuk melihat variasi dari data tersebut (Riyanto \& Wikarya, 2018).

Metode analisis inferensial yang digunakan adalah regresi linier berganda. Persamaan model estimasi ditulis sebagai berikut: 
ipd $=\beta_{0}+\beta_{1}$ agama $+\beta_{2}$ etnis $+\beta_{3}$ bahasa $+\beta_{4}$ tpgf $+\beta_{5}$ lapus $+\beta_{6} p t+\beta_{7}$ terampil $+\beta_{8}$ nakes + $\beta_{\text {girigasi }}+\beta_{10}$ kredit

Sebelum menguji variabel dengan regresi linier berganda, dilakukan uji multikolinearitas, uji heteroskedastisitas dan uji normalitas untuk memenuhi asumsi yang diperlukan dalam regresi linier berganda. Uji multikolinearitas dilakukan untuk menguji asumsi multikolinearitas pada regresi linier berganda dengan melihat nilai VIF dan nilai tolerance. Uji heteroskedastisitas digunakan untuk menguji asumsi heteroskedastisitas dengan menggunakan grafik scatterplots antara regression studentized residual dan regression standardized predicted value. Uji normalitas digunakan untuk melihat pola distribusi normal dengan menggunakan grafik normal P-P plot of regression standardized residual.

\section{HASIL DAN PEMBAHASAN}

\section{Deskripsi Desa Menurut Keragaman Agama, Etnis, Bahasa, dan Tingkat Pembangunannya}

Hasil analisis deskriptif pada Tabel 3 menunjukkan bahwa 12,498 desa (17.33 persen) merupakan desa tertinggal, 54,066 desa (74.97 persen) merupakan desa berkembang, dan 5,557 desa (7.71 persen) merupakan desa mandiri. Sebagian besar desa merupakan desa berkembang, akan tetapi desa tertinggal masih lebih dari dua kali lipat dari desa mandiri.

Jika dilihat dari keragaman agama, desa dengan warga yang hanya memeluk satu agama tertentu (50.27 persen) sedikit lebih banyak dibandingkan desa dengan warga yang memeluk lebih dari satu agama (49.73 persen). Hal ini menunjukkan bahwa warga desa di Indonesia sedikit lebih homogen dalam hal agama yang dianut. Persentase desa tertinggal dengan warga yang memiliki agama yang sama (21.05 persen) lebih tinggi bila dibandingkan dengan desa tertinggal dengan warga yang multi agama (13.57 persen), sedangkan persentase desa mandiri dengan warga yang memeluk agama yang sama $(3.30$ persen $)$ lebih rendah dibandingkan desa mandiri yang multi agama (12.16 persen). Sebelum dikontrol terhadap faktor lain, desa yang multi agama, $3.68 \mathrm{kali}$ lebih cenderung untuk menjadi desa mandiri dibandingkan desa dengan warga yang memeluk satu agama yang sama dan desa yang tidak multi agama 1.55 kali lebih cenderung untuk menjadi desa tertinggal dibandingkan desa yang multi agama.

Berdasarkan keragaman etnis, 68.96 persen desa merupakan desa dengan warga yang terdiri dari lebih dari satu etnis. Persentase desa berkembang dan desa mandiri yang terdiri dari warga multi etnis lebih tinggi dibandingkan persentase desa berkembang dan desa mandiri dengan warga yang tidak multi etnis. Persentase desa tertinggal yang terdiri dari warga dengan satu etnis (26.76 persen) lebih tinggi dibandingkan dengan persentase desa tertinggal yang terdiri dari warga yang multi etnis (13.08 persen). Sebelum dikontrol terhadap faktor lain, desa dengan warga yang tidak multi etnis 2.05 kali lebih cenderung untuk menjadi desa tertinggal dibandingkan desa dengan warga yang multi etnis.

Berdasarkan bahasa yang dipakai seharihari, desa dengan warga yang berkomunikasi dengan lebih dari satu bahasa (64.45 persen) lebih banyak dibandingkan desa dengan warga yang berkomunikasi dengan hanya satu bahasa (35.55 persen). Persentase desa tertinggal dengan warga yang berkomunikasi menggunakan satu bahasa (20.68 persen) lebih tinggi dibandingkan persentase desa tertinggal dengan warga yang berkomunikasi menggunakan lebih dari satu bahasa (15.48 persen). Desa mandiri dengan warga yang berkomunikasi menggunakan lebih dari satu bahasa (8.82 persen) lebih banyak dibandingkan desa mandiri dengan warga yang berkomunikasi menggunakan satu bahasa (5.68 persen). Sebelum dikontrol dengan faktor lain, desa dengan warga yang berkomunikasi dengan lebih dari satu bahasa 1.55 kali lebih cenderung untuk menjadi desa mandiri dibandingkan desa dengan warga yang berkomunikasi dengan satu bahasa.

Hasil analisis deskriptif menunjukkan desa dengan warga yang multi agama, multi 
etnis dan multi bahasa lebih cenderung untuk menjadi desa mandiri, sedangkan desa dengan warga yang tidak multi agama, tidak multi etnis, dan tidak multi bahasa lebih cenderung untuk menjadi desa tertinggal. Hal ini menunjukkan bahwa, sebelum dikontrol oleh faktor lain, keragaman agama, etnis, dan bahasa warga di suatu desa dapat menjadi pendorong pembangunan di desa tersebut. Menurut Ahmad \& Amin (2020) diversifikasi etnis dapat menjadi mesin untuk meningkatkan produktivitas dan inovasi karena masing-masing etnis memiliki keahlian yang berbeda yang dapat saling melengkapi satu sama lain. Etnis yang bercampur juga dapat menyatukan kemampuan, pengalaman, dan budaya saat produktif sehingga menghasilkan inovasi dan kreatifitas.

Bila melihat kondisi geografis desa, 74,68 persen desa merupakan desa dengan topografi berupa dataran. Persentase desa mandiri yang berupa dataran (9.36 persen) lebih tinggi dibandingkan persentase desa mandiri yang bukan dataran (2.84 persen). Akan tetapi, persentase desa tertinggal yang bukan dataran (34.37 persen) lebih tinggi dibandingkan persentase desa tertinggal yang berupa dataran (11.53 persen).

Sebagian besar desa (93.82 persen) memiliki warga yang sebagian besar bekerja pada sektor pertanian, sedangkan hanya 6.18 persen desa dengan sebagian besar warganya bekerja pada sektor nonpertanian. Persentase desa mandiri dengan sebagian besar warganya bekerja pada sektor nonpertanian (37.44 persen) lebih tinggi dibandingkan persentase desa mandiri yang sebagian besar warganya bekerja pada sektor pertanian (5.74 persen).

Persentase desa mandiri dengan keberadaan infrastruktur pendidikan seperti perguruan tinggi atau lembaga keterampilan lebih tinggi dibandingkan desa mandiri tanpa infrastruktur pendidikan. Pola yang sama juga terlihat pada keberadaan tenaga kesehatan di desa, dimana persentase desa mandiri dengan tenaga kesehatan lebih tinggi dibandingkan persentase desa mandiri tanpa tenaga kesehatan.

Bila melihat infrastruktur irigasi, persentase desa tertinggal tanpa infrastruktur irigasi lebih tinggi dibandingkan desa tertinggal dengan infrastruktur irigasi. Untuk penyaluran kredit, desa tertinggal yang warganya tidak mendapatkan kredit lebih tinggi dibandingkan desa tertinggal yang warganya mendapatkan kredit.

Secara umum, kebanyakan desa tertinggal memiliki keadaan dimana desa tersebut tidak multi agama, tidak multi etnis, tidak multi bahasa, bukan berupa dataran, sebagian besar warganya bekerja pada sektor pertanian, tidak terdapat perguruan tinggi ataupun lembaga keterampilan, tidak terdapat tenaga kesehatan, tidak terdapat saluran irigasi, dan tidak terdapat warga yang menerima kredit setahun terakhir. Secara umum, kebanyakan desa mandiri merupakan desa yang multi agama, multi etnis, multi bahasa, berupa dataran, sebagian besar warganya bekerja pada sektor nonpertanian, terdapat perguruan tinggi ataupun lembaga keterampilan, terdapat tenaga kesehatan, terdapat saluran irigasi, dan terdapat warga yang menerima kredit setahun terakhir.

Tabel 3. Pembangunan desa menurut karakteristik desa

\begin{tabular}{|c|c|c|c|c|c|}
\hline & & \multicolumn{3}{|c|}{ Tingkat pembangunan desa } & \multirow[t]{2}{*}{ Total } \\
\hline & & $\begin{array}{c}\text { Desa } \\
\text { tertinggal }\end{array}$ & $\begin{array}{c}\text { Desa } \\
\text { berkembang }\end{array}$ & Desa mandiri & \\
\hline \multirow{4}{*}{ Multi agama } & \multirow{2}{*}{ Tidak } & 7,631 & 27,425 & 1,197 & 36,253 \\
\hline & & $21.05 \%$ & $75.65 \%$ & $3.30 \%$ & $50.27 \%$ \\
\hline & \multirow{2}{*}{$\mathrm{Ya}$} & 4,867 & 26,641 & 4,360 & 35,868 \\
\hline & & $13.57 \%$ & $74.28 \%$ & $12.16 \%$ & $49.73 \%$ \\
\hline
\end{tabular}




\begin{tabular}{|c|c|c|c|c|c|}
\hline & & \multicolumn{3}{|c|}{ Tingkat pembangunan desa } & \multirow[t]{2}{*}{ Total } \\
\hline & & $\begin{array}{c}\text { Desa } \\
\text { tertinggal }\end{array}$ & $\begin{array}{c}\text { Desa } \\
\text { berkembang }\end{array}$ & Desa mandiri & \\
\hline \multirow{4}{*}{ Multi etnis } & \multirow{2}{*}{ Tidak } & 5,991 & 15,561 & 836 & 22,388 \\
\hline & & $26.76 \%$ & $69.51 \%$ & $3.73 \%$ & $31.04 \%$ \\
\hline & \multirow[b]{2}{*}{$\mathrm{Ya}$} & 6,507 & 38,505 & 4,721 & 49,733 \\
\hline & & $13.08 \%$ & $77.42 \%$ & $9.49 \%$ & $68.96 \%$ \\
\hline \multirow{4}{*}{ Multi bahasa } & \multirow{2}{*}{ Tidak } & 5,301 & 18,881 & 1,456 & 25,638 \\
\hline & & $20.68 \%$ & $73.64 \%$ & $5.68 \%$ & $35.55 \%$ \\
\hline & \multirow{2}{*}{ Ya } & 7,197 & 35,185 & 4,101 & 46,483 \\
\hline & & $15.48 \%$ & $75.69 \%$ & $8.82 \%$ & $64.45 \%$ \\
\hline \multirow{4}{*}{ Topografi } & \multirow{2}{*}{ Bukan dataran } & 6,296 & 11,500 & 521 & 18,317 \\
\hline & & $34.37 \%$ & $62.78 \%$ & $2.84 \%$ & $25.40 \%$ \\
\hline & \multirow{2}{*}{ Dataran } & 6,202 & 42,566 & 5,036 & 53,804 \\
\hline & & $11.53 \%$ & $79.11 \%$ & $9.36 \%$ & $74.60 \%$ \\
\hline \multirow{4}{*}{ Lapangan usaha } & \multirow{2}{*}{ Pertanian } & 12,377 & 51,397 & 3,887 & 67,661 \\
\hline & & $18.29 \%$ & $75.96 \%$ & $5.74 \%$ & $93.82 \%$ \\
\hline & \multirow{2}{*}{ Nonpertanian } & 121 & 2,669 & 1,670 & 4,460 \\
\hline & & $2.71 \%$ & $59.84 \%$ & $37.44 \%$ & $6.18 \%$ \\
\hline \multirow{4}{*}{ Perguruan tinggi } & \multirow{2}{*}{ Tidak ada } & 12,486 & 53,528 & 5,050 & 71,064 \\
\hline & & $17.57 \%$ & $75.32 \%$ & $7.11 \%$ & $98.53 \%$ \\
\hline & \multirow{2}{*}{ Ada } & 12 & 538 & 507 & 1,057 \\
\hline & & $1.14 \%$ & $50.90 \%$ & $47.97 \%$ & $1.47 \%$ \\
\hline \multirow{4}{*}{$\begin{array}{c}\text { Lembaga } \\
\text { keterampilan }\end{array}$} & \multirow{2}{*}{ Tidak ada } & 12,435 & 50,695 & 3,628 & 66,758 \\
\hline & & $18.63 \%$ & $75.94 \%$ & $5.43 \%$ & $92.56 \%$ \\
\hline & \multirow{2}{*}{ Ada } & 63 & 3,371 & 1,929 & 5,363 \\
\hline & & $1.17 \%$ & $62.86 \%$ & $35.97 \%$ & $7.44 \%$ \\
\hline \multirow{4}{*}{ Tenaga kesehatan } & \multirow{2}{*}{ Tidak ada } & 6,166 & 4,950 & 39 & 11,155 \\
\hline & & $55.28 \%$ & $44.37 \%$ & $0.35 \%$ & $15.47 \%$ \\
\hline & \multirow{2}{*}{ Ada } & 6,332 & 49,116 & 5,518 & 60,966 \\
\hline & & $10.39 \%$ & $80.56 \%$ & $9.05 \%$ & $84.53 \%$ \\
\hline \multirow{3}{*}{ Irigasi } & \multirow{2}{*}{ Tidak ada } & 11,189 & 28,496 & 1,847 & 41,532 \\
\hline & & $26.94 \%$ & $68.61 \%$ & $4.45 \%$ & $57.59 \%$ \\
\hline & Ada & 1,309 & 25,570 & 3,710 & 30,589 \\
\hline
\end{tabular}




\begin{tabular}{|c|c|c|c|c|c|}
\hline & & \multicolumn{3}{|c|}{ Tingkat pembangunan desa } & \multirow[t]{2}{*}{ Total } \\
\hline & & $\begin{array}{c}\text { Desa } \\
\text { tertinggal }\end{array}$ & $\begin{array}{c}\text { Desa } \\
\text { berkembang }\end{array}$ & Desa mandiri & \\
\hline & & $4.28 \%$ & $83.59 \%$ & $12.13 \%$ & $42.41 \%$ \\
\hline \multirow{4}{*}{ Kredit } & \multirow{2}{*}{ Tidak ada } & 11,290 & 25,812 & 1,232 & 38,334 \\
\hline & & $29.45 \%$ & $67.33 \%$ & $3.21 \%$ & $53.15 \%$ \\
\hline & \multirow{2}{*}{ Ada } & 1,208 & 28,254 & 4,325 & 33,787 \\
\hline & & $3.58 \%$ & $83.62 \%$ & $12.80 \%$ & $46.85 \%$ \\
\hline \multirow{2}{*}{\multicolumn{2}{|c|}{ Total }} & 12,498 & 54,066 & 5,557 & 72,121 \\
\hline & & $17.33 \%$ & $74.97 \%$ & $7.71 \%$ & $100.00 \%$ \\
\hline
\end{tabular}

Sumber : PODES2014 dan IPD2018, diolah

\section{Pengaruh Keragaman Agama, Etnis, Bahasa Terhadap Pembangunan Desa}

Hasil uji multikolinearitas, heteroskedasitas, dan normalitas menunjukkan asumsi yang terpenuhi untuk melakukan analisis regresi berganda. Pengujian Global Test dengan uji $\mathrm{F}$ menunjukkan nilai yang signifikan $(p-$ value $<0.05$ persen) sehingga dapat disimpulkan bahwa variabel bebas secara bersama-sama dapat digunakan membentuk model.

Hasil regresi linear berganda pada Tabel 4 menyajikan koefisien dan signifikansi masingmasing variabel. Hasil analisis menunjukkan bahwa seluruh variabel bebas signifikan pada $p$ value $<0.01$. Berdasarkan hasil estimasi, model persamaan yang digunakan dituliskan sebagai berikut :

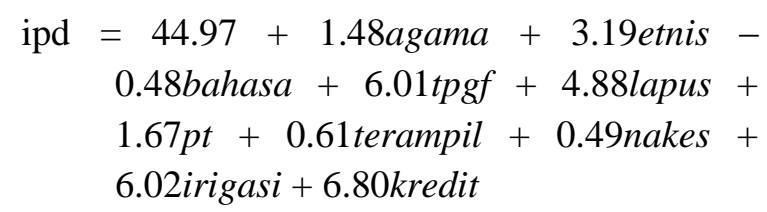

Nilai koefisien variabel multi agama sebesar 1.48 yang berarti bahwa keberadaan warga yang memeluk agama yang berbeda berhubungan positif dengan pembangunan desa. Desa dengan warga yang multi agama akan menambah IPD 1.48 poin lebih tinggi dibandingkan desa dengan warga yang tidak multi agama. Hal ini menunjukkan bahwa keragaman agama yang dipeluk warga dalam suatu desa dapat memberikan dampak positif terhadap pembangunan desa. Menurut Ying et al. (2017) keragaman agama dapat meningkatkan produktivitas yang dapat meningkatkan pembangunan. Kumpulan individu yang beragam memiliki keahlian dan interpretasi terhadap masalah yang berbeda sehingga dapat meningkatkan produktivitas yang selanjutnya dapat meningkatkan pembangunan (Ying et al., 2017).

Hasil estimasi regresi linier berganda menghasilkan nilai koefisien multi etnis sebesar 3.19. Desa dengan warga yang berasal dari etnis yang berbeda dapat memiliki IPD 3.19 poin lebih tinggi dibandingkan desa dengan warga yang berasal dari satu etnis yang sama. Hal ini menunjukkan hubungan yang positif antara keragaman etnis dan pembangunan desa, dimana desa dengan warga yang beragam etnis dapat meningkatkan pembangunan desa. Hal tersebut sejalan dengan penelitian Churchill et al. (2020) dimana menurutnya keragaman etnis memiliki pengaruh positif terhadap pembangunan sumber daya manusia yang dapat mendorong pembangunan. Keragaman etnis dapat meningkatkan pembangunan melalui modal sosial, dimana dengan tingginya modal sosial, kendali sosial dan keterlibatan pemuda dalam pembangunan juga meningkat. Selain itu, keragaman etnis yang dapat mendorong pembangunan menunjukkan bahwa efek positif keragaman terhadap pembangunan lebih tinggi 
dari efek negatif, seperti konflik, yang dapat timbul karenanya (Churchill et al., 2020).

Berbeda dengan variabel multi agama dan multi etnis, hasil estimasi menunjukkan nilai koefisien yang negatif untuk variabel multi bahasa, yaitu -0.48. Desa dengan warga yang memakai lebih dari satu bahasa sehari-hari dapat menurunkan IPD sebesar 0.48 poin dibandingkan desa dengan warga yang menggunakan satu bahasa sehari-hari. Terdapat hubungan negatif antara keragaman bahasa yang digunakan sehari-hari dengan pembangunan desa. Pembangunan desa dapat meningkat bila warga yang tinggal pada desa tersebut menggunakan satu bahasa sehari-hari. Menurut Churchill et al. (2020) satu bahasa yang digunakan dapat meningkatkan potensi modal sosial yang dapat meningkatkan pembangunan. Selain itu, kesatuan bahasa dapat menurunkan ketegangan akan perbedaan etnis, dimana ketegangan akan perbedaan etnis dapat menimbulkan konflik yang menghambat pembangunan (Churchill \& Smyth, 2017).

Topografi desa juga memiliki pengaruh signifikan terhadap pembangunan desa. Pada saat variabel lain konstan, desa dengan topografi berupa dataran dapat berkontribusi positif terhadap kenaikan IPD sebesar 6.01 poin. Selain itu, lapangan usaha nonpertanian juga memiliki dampak positif yang signifikan terhadap pembangunan desa. Pada saat variabel lain konstan, desa dengan sebagian besar warganya bekerja pada sektor nonpertanian dapat meningkatkan IPD sebesar 4.88 poin.

Jumlah fasilitas pendidikan di desa memiliki hubungan yang positif terhadap IPD. Semakin banyak jumlah fasilitas pendidikan di desa tersebut, maka IPD yang dimiliki juga semakin tinggi. Ketika jumlah perguruan tinggi bertambah satu, maka IPD dapat meningkat sebesar 1.67 poin. Ketika jumlah lembaga keterampilan bertambah satu, maka IPD dapat meningkat sebesar 0.61 poin. Selain itu, jumlah tenaga kesehatan juga memiliki dampak positif terhadap pembangunan desa, dimana peningkatan satu tenaga kesehatan dapat berkontribusi positif terhadap IPD sebesar 0.49 poin.
Fasilitas irigasi dan kredit juga memiliki dampak positif terhadap pembangunan desa. Pada saat variabel lain konstan, keberadaan fasilitas irigasi di desa dapat meningkatkan IPD sebesar 6.02 poin. Selain itu, keberadaan warga yang menerima fasilitas kredit di desa satu tahun terakhir dapat berkontribusi positif terhadap kenaikan IPD sebesar 6.80 poin.

Tabel 4. Hasil regresi linier berganda

\begin{tabular}{lc}
\multicolumn{1}{c}{ Variabel } & Koefisien ( $\beta$ \\
\hline Konstanta & $44.97 * * *$ \\
Multi agama & \\
Ya & $1.48 * * *$ \\
Tidak (acuan) & \\
Multi etnis \\
Ya \\
Tidak (acuan) \\
Multi bahasa \\
Ya \\
Tidak (acuan) \\
Topografi \\
Dataran \\
Bukan dataran (acuan) \\
Lapangan usaha
\end{tabular}

Nonpertanian

$4.88 * * *$

Pertanian (acuan)

$\begin{array}{lll}\text { Perguruan tinggi } & 1.67 & * * * \\ \text { Lembaga keterampilan } & 0.61 & * * * \\ \text { Tenaga kesehatan } & 0.49 & * * *\end{array}$

Irigasi

$\begin{array}{ll}\text { Ada } & 6.02 * * *\end{array}$

Tidak ada (acuan)

Kredit 


\begin{tabular}{lc}
\hline \multicolumn{1}{c}{ Variabel } & Koefisien $(\boldsymbol{\beta})$ \\
\hline Ada & $6.80 * * *$ \\
Tidak ada $($ acuan $)$ & \\
\hline $\begin{array}{l}\text { Keterangan: } * * *=\mathrm{p}-\text {-value }<0.01 ; * *=\mathrm{p}-\text { value }<0.05 ; \\
*=\mathrm{p}-\text { value }<0.1\end{array}$ \\
Sumber: PODES2014, IPD2018, diolah penulis
\end{tabular}

\section{KESIMPULAN}

Berdasarkan hasil analisis deskriptif, kebanyakan desa di Indonesia ditinggali oleh warga dengan agama yang sama, etnis yang berbeda, dan menggunakan lebih dari satu bahasa sehari-hari. Desa yang memiliki warga dengan agama yang sama, etnis yang sama, dan memakai satu bahasa sehari-hari cenderung merupakan desa tertinggal. Desa yang memiliki warga dengan agama yang berbeda, etnis yang berbeda, dan menggunakan lebih dari satu bahasa sehari-hari cenderung merupakan desa mandiri. Hasil analisis deskriptif mengenai keragaman bahasa berlawanan dengan hasil inferensial, dimana menurut analisis deskriptif desa tertinggal cenderung menggunakan satu bahasa, sedangkan desa mandiri cenderung menggunakan lebih dari satu bahasa. Hal tersebut dimungkinkan dapat terjadi karena analisis deskriptif belum mengontrol variabel lain yang juga berpengaruh terhadap pembangunan desa. Desa dengan topografi berupa dataran, sebagian warganya bekerja pada sektor nonpertanian, terdapat perguruan tinggi, lembaga keterampilan, tenaga kesehatan, fasilitas irigasi, dan terdapat warga yang mendapat fasilitas kredit setahun terakhir cenderung merupakan desa mandiri.

Berdasarkan hasil inferensial, setelah dikontrol oleh variabel topografi, lapangan usaha, jumlah perguruan tinggi, jumlah lembaga keterampilan, jumlah tenaga kesehatan, keberadaan irigasi dan keberadaan kredit, keberadaan warga yang multi agama, multi etnis, dan multi bahasa memberikan dampak yang signifikan terhadap pembangunan desa. Keberadaan warga yang multi agama dalam desa memberikan dampak positif pada pembangunan desa. Hal tersebut sejalan dengan penelitian
Ying et al. (2017) dimana keragaman agama memiliki pengaruh positif yang signifikan terhadap pembangunan daerah. Keberadaan warga yang multi etnis juga memberikan dampak positif terhadap pembangunan desa. Penelitian Churchill et al. (2020) juga menunjukkan bahwa keragaman etnis dapat meningkatkan pembangunan sumber daya manusia yang dapat menunjang pembangunan. Sedangkan keragaman bahasa yang digunakan sehari-hari memiliki dampak negatif terhadap pembangunan. Hal tersebut sejalan dengan penelitian Churchill \& Smyth (2017) yang menunjukkan bahwa keberagaman bahasa memiliki hubungan positif dengan kemiskinan.

Keragaman agama dan etnis memberikan dampak positif terhadap pembangunan desa dimungkinkan melalui modal sosial yang meningkatkan partisipasi dalam pembangunan, serta keahlian yang berbeda yang dapat meningkatkan produktivitas. Akan tetapi, keragaman bahasa yang digunakan sehari-hari justru memberikan dampak negatif terhadap pembangunan, kemungkinan dikarenakan penggunaan bahasa yang berbeda akan lebih menonjolkan perbedaan etnis yang ada sehingga ketegangan akan konflik dapat meningkat dan dapat menghambat pembangunan. Hal tersebut menunjukkan bahwa keragaman agama dan etnis dalam desa diperlukan untuk pembangunan sedangkan bahasa yang sama diperlukan sebagai pemersatu keragaman tersebut.

Selain keragaman agama, etnis, dan bahasa, faktor topografi desa, lapangan usaha sebagian besar penduduk desa, jumlah perguruan tinggi, jumlah lembaga keterampilan, jumlah tenaga kesehatan di desa, keberadaan fasilitas irigasi, serta keberadaan warga yang menerima fasilitas kredit di desa juga signifikan berhubungan dengan pembangunan desa. Dari seluruh variabel tersebut, fasilitas kredit, jumlah tenaga kesehatan, dan topografi desa memberikan dampak yang paling tinggi terhadap pembangunan desa. 


\section{DAFTAR PUSTAKA}

Ahmad, N. \& Amin, S. (2020). Does ethnic polarization stimulate or relegate trade and environmental performance? A global perspective. Environment, Development and Sustainability, 22 (7), 6513-6536. https://doi.org/10.1007/s10668-01900497-z

Anggriyani, D. S. \& Dartanto, T. (2019). Unity in diversity: Socioeconomic aspects and growth of conflict in indonesia. International Journal of Business and Society, 20 (S1), 197-209.

Bappenas. (2017). Ringkasan Metadata Tujuan Pembangunan Berkelanjutan (TPB)/ Indikator Sustainable Development Goals (SDGs) Indonesia. In Kementerian PPN / Bappenas.

Barrios, E. B. (2008). Infrastructure and rural development: Household perceptions on rural development. Progress in Planning, $70 \quad(1), \quad 1-44$. https://doi.org/10.1016/j.progress.2008.04 .001

BPS. (2011a). Kewarganegaraan, Suku Bangsa, Agama, dan Bahasa Sehari-hari Penduduk Indonesia.

BPS. (2011b). Statistik Potensi Desa Indonesia 2011.

BPS. (2014). Statistik Potensi Desa Indonesia [Village Potential Statistics of Indonesia] 2014.

BPS. (2018a). Indeks Pembangunan Desa 2018.

BPS. (2018b). Indonesia Population Projection 2015-2045 Result of SUPAS 2015 (Revised Edition).

BPS. (2018c). Village Potential Statistics of Indonesia 2018.

Cowie, P., Townsend, L., \& Salemink, K. (2020). Smart rural futures: Will rural areas be left behind in the 4th industrial revolution? Journal of Rural Studies, 79 (August), $169-176$ https://doi.org/10.1016/j.jrurstud.2020.08. 042

Churchill, S. A., Madhoo, Y. N., \& Nath, S. (2020). Ethnic diversity and human capital development in India: A disaggregated analysis at the state and district levels. Applied Economics, 52 (5), 506-518. https://doi.org/10.1080/00036846.2019.16 46880
Churchill, S. A. \& Smyth, R. (2017). Ethnic Diversity and Poverty. World Development, 95 (3), 285-302. https://doi.org/10.1016/j.worlddev.2017.0 2.032

Faoziyah, U. \& Salim, W. (2020). Seeking prosperity through village proliferation: An evidence of the implementation of village funds (Dana Desa) in Indonesia. Journal of Regional and City Planning, 31 (2), 97-121. https://doi.org/10.5614/jpwk.2020.31.2.1

Grabowski, M. \& Laidler, P. (2018). The Economic and Political Dimensions of Development in the 21st Century.

Harsono, M. (2002). Prosedur Pengujian Variabel Kontrol Dan Moderator Dalam Penelitian Perilaku Dengan Menggunakan Spss 10.00*). Jurnal Jurusan Manajemen Fakultas Ekonomi Universitas Sebelas Maret Variabel, 1-7.

Huntington, S. P. (1993). The clash of civilizations? Foreign Affairs, 72 (3), $22-$ 49. https://doi.org/10.4324/978100306096350

Marsden, T. (2010). Mobilizing the regional eco-economy: Evolving webs of agri-food and rural development in the UK. Cambridge Journal of Regions, Economy and Society, 3 (2), 225-244. https://doi.org/10.1093/cjres/rsq010

Nurlinah, Haryanto, \& Sunardi. (2020). New development, old migration, and governance at two villages in Jeneponto, Indonesia. World Development Perspectives, 19 (June), 100223. https://doi.org/10.1016/j.wdp.2020.10022 3

Qin, X., Li, Y., Lu, Z., \& Pan, W. (2020). What makes better village economic development in traditional agricultural areas of China? Evidence from 338 villages. Habitat International, 106 (July), 102286.

https://doi.org/10.1016/j.habitatint.2020.1 02286

Rennie, F. (2003). Rural health workers as a resource for rural development. Rural Society, $13 \quad$ (2), 126-137. https://doi.org/10.5172/rsj.351.13.2.126

Riyanto \& Wikarya, U. (2018). Statistika Ekonomi dan Bisnis (1st ed.). Jakarta: Mitra Wacana Media. 
Journal of Regional and Rural Development Planning (Jurnal Perencanaan Pembangunan Wilayah dan Perdesaan) Juni 2021, 5 (2): 77-90

Salim, A., Bulan, W. R., Untung, B., Laksono, I., \& Brock, K. (2017). Indonesia 's Village Law: enabler or constraint for more accountable governance?

Xiaojian, L. \& Xinsheng, F. (2010). Geography and rural household income: A village level study in Henan Province, China. Chinese Geographical Science, 20 (1), 001-008. https://doi.org/10.1007/s11769010-0001-8

Ying, Z., Liu, S., Bao, S., \& Zhou, J. (2017). Religious diversity and regional development in China. China Economic Review, 46 (August), 1-9. https://doi.org/10.1016/j.chieco.2017.08.0 03 